\title{
Physiographical and Hydrological Analysis of Yalamlam Basin, Makkah Al-Mukarramah Area
}

\author{
Ali M. Subyani and TariQ H. Bayumi \\ Faculty of Earth Sciences, King Abdulaziz University, \\ Jeddah, Saudi Arabia \\ Received: 9/6/2002 Revised: 25/11/2002 Accepted: 31/12/2002
}

Aвstract. Wadi Yalamlam is one of the Arabian Shield Wadis, located $70 \mathrm{~km}$ south of Makkah Al-Mukarramah city. The main rock units consist of Precambrian crystalline, meta-volcanic and metasedimentary rocks, with local Tertiary and Quaternary basalt flows. The geographic setting of Wadi Yalamlam basin can be divided into three main zones: the Red Sea coastal plain (Tihamah), the hills, and the Scarp-Hijaz Mountains. The catchment area starts from the Hijaz Escarpment (Ashafa area) in the east to the Red Sea at the west .Morphometric analysis of the basin shows that it drains a large catchment area of about $1600 \mathrm{~km}^{2}$, very elongated, high relief, and of a moderate drainage density.

The mean annual and seasonal rainfalls of hydrological stations around the study area have been analyzed.Seasonal rainfall occurs in the mountains area, but varies from year to year. It often occurs as thunderstorms of high intensity during a local storm followed by dry periods. The average annual rainfall exceeds $200 \mathrm{~mm}$ in the mountains and decreases to $80 \mathrm{~mm}$ towards the Red Sea coast. In addition, Wadi Yalamlam has surface running water in the upstream most of the year. Runoff hydrographs of 0.5 hour duration were constructed, based on Snyder method, for three sub-basins of wadi Yalamlam.

\section{Introduction}

Wadi Yalamlam, called Wadi Sa'diyah in some reports, is one of the important Wadis in Makkah Al-Mukarramah area and lies about $125 \mathrm{~km}$ south east of Jeddah, and $70 \mathrm{~km}$ south of Makkah Al-Mukarramah city, Fig. 1. It flows into the 


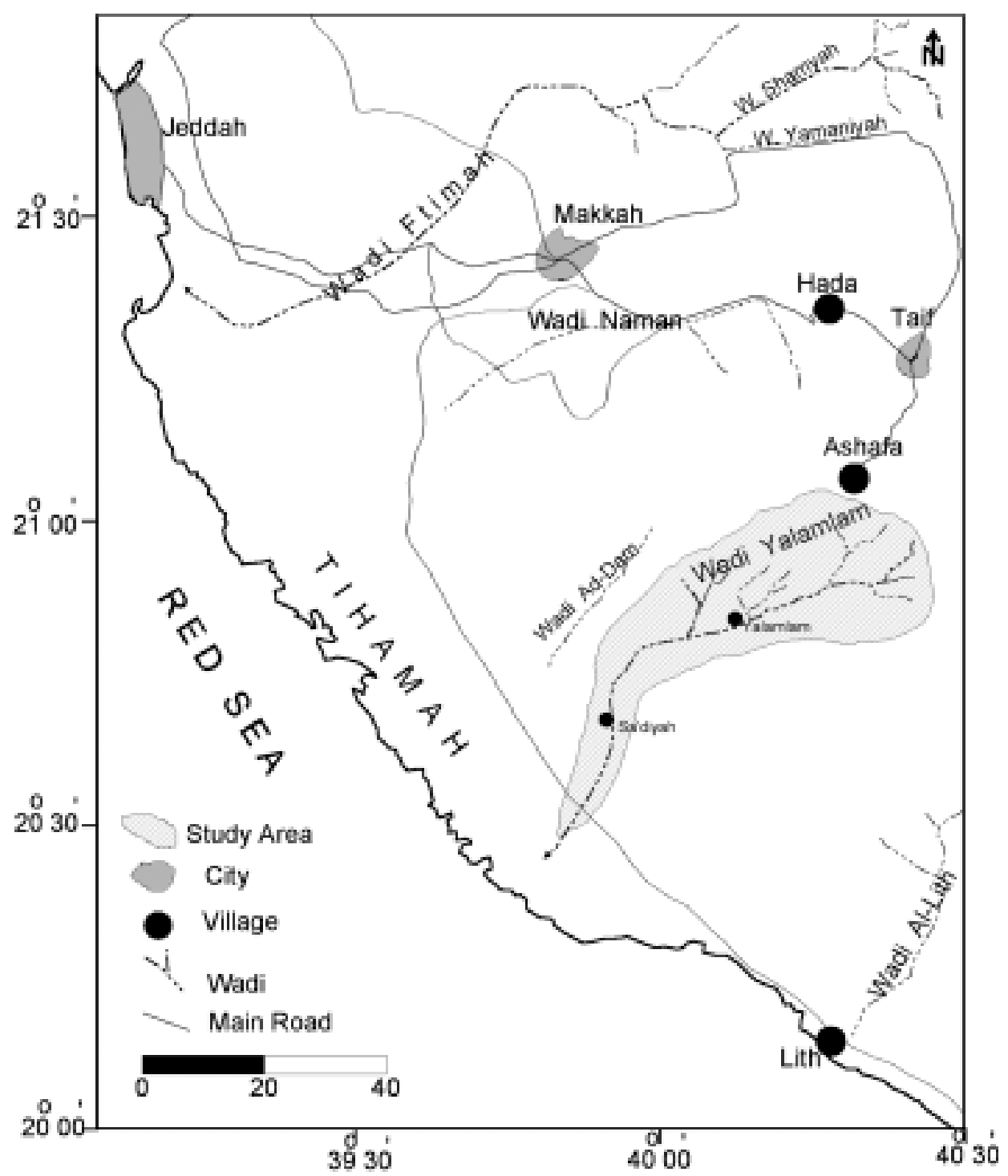

FIG. 1. Location map and geographic position of Wadi Yalamlam. 
Red Sea coastal plain, Tihamah. This Wadi is bounded by Latitudes $20^{\circ} 30^{\prime}$ and $21^{\circ} 10^{\prime} \mathrm{N}$ and Longitudes $39^{\circ} 45^{\prime}$ and $40^{\circ} 30^{\prime} \mathrm{E}$, this Wadi (Yalamlam) is part of the Scarp-Hijaz Mountains of the Arabian Shield, which extends from north to south parallel to the Red Sea. This escarpment is one of the outstanding landscape features of Saudi Arabia. The area is characterized by three physiographic units, namely, the Red Sea coastal plain, the hills, and the Scarp-Hijaz mountains. This basin drains a wide catchment area of about $1600 \mathrm{~km}^{2}$. The catchment area, which starts from the Scarp-mountains, is characterized by high amount of annual rainfall of more than $200 \mathrm{~mm}$. Towards the drainage opening on the plain, the Wadi loses its defined course and becomes wide spans of sheet wash, while further downstream it is integrated as part of the Red Sea coastal plain.

The only paved road to reach the mouth of this Wadi is the Makkah AlMukarramah-Jeddah-Jizan road along the Red Sea coastline, as shown in Fig. 1. Several tracks connect the lower parts of the Wadi to the upper reaches in the east, near Ashafa foothills. The activities of the local population in Wadi Yalamlam are controlled by different geographical, economical, and social factors. However, the majority of the population is concentrated in the middle and down stream areas, at Yalamlam and Sa'diyah villages.

Due to low income from the small agricultural business and the lack of civil services, there is an increases in migration from the Wadi to neighboring cities such as Makkah Al-Mukarramah, Jeddah and Al-Lith. From the agricultural development point of view, the upper reaches of the Wadi have limited agricultural potential, while the middle and lower sites offer better potentialities due to better flood distribution (El-Khatib, 1980; Noory 1983; Subyani and Bayumi, 2001).

The purpose of this paper is to assemble and analyze the geological, physiographical, and hydrological characteristics of Wadi Yalamlam basin.

\section{Geological Setting}

The Arabian Shield is mainly composed of Precambrian crystalline, metavolcanic and meta-sedimentary rocks with their associated plutonic equivalents, together with local Tertiary and Quaternary basalt flows. These rocks form the mountain ranges east of the Red Sea coastal plain. The last major igneous activity, which had a great impact on changing the Wadi courses in the Arabian Shield is the extrusions of alkaline basaltic lava flows on the craton and along the Red Sea Coast. These geologic features are reflected in the form of the topographic and morphometric variations and also in the human settlements and their activities in the area. 
Wadi Yalamlam runs through the middle of the Arabian Shield to the Red Sea. A systematic geological mapping survey of the Shield started in the late 1950's. Brown et al. (1963) published a geologic map of the entire Arabian Peninsula at 1:2,000,000 scale. Geologic, petrographic and structural quadrangle maps were published at 1:500,000 to 1:100,000 scale (Alshanti, 1993). In the study area, the only detailed geological study was made by Wier and Hadley (1975) as a reconnaissance geology of Wadi Sa'diyah (Yalamlam) quadrangle at 1:100,000 scale. The following is a summary of the geology of Wadi Yalamlam. (Brown et al., 1963; Wier and Hadley, 1975; Pallister, 1982; Moore and Al-Rehaili,1989; Alshanti, 1993) Fig. 2.

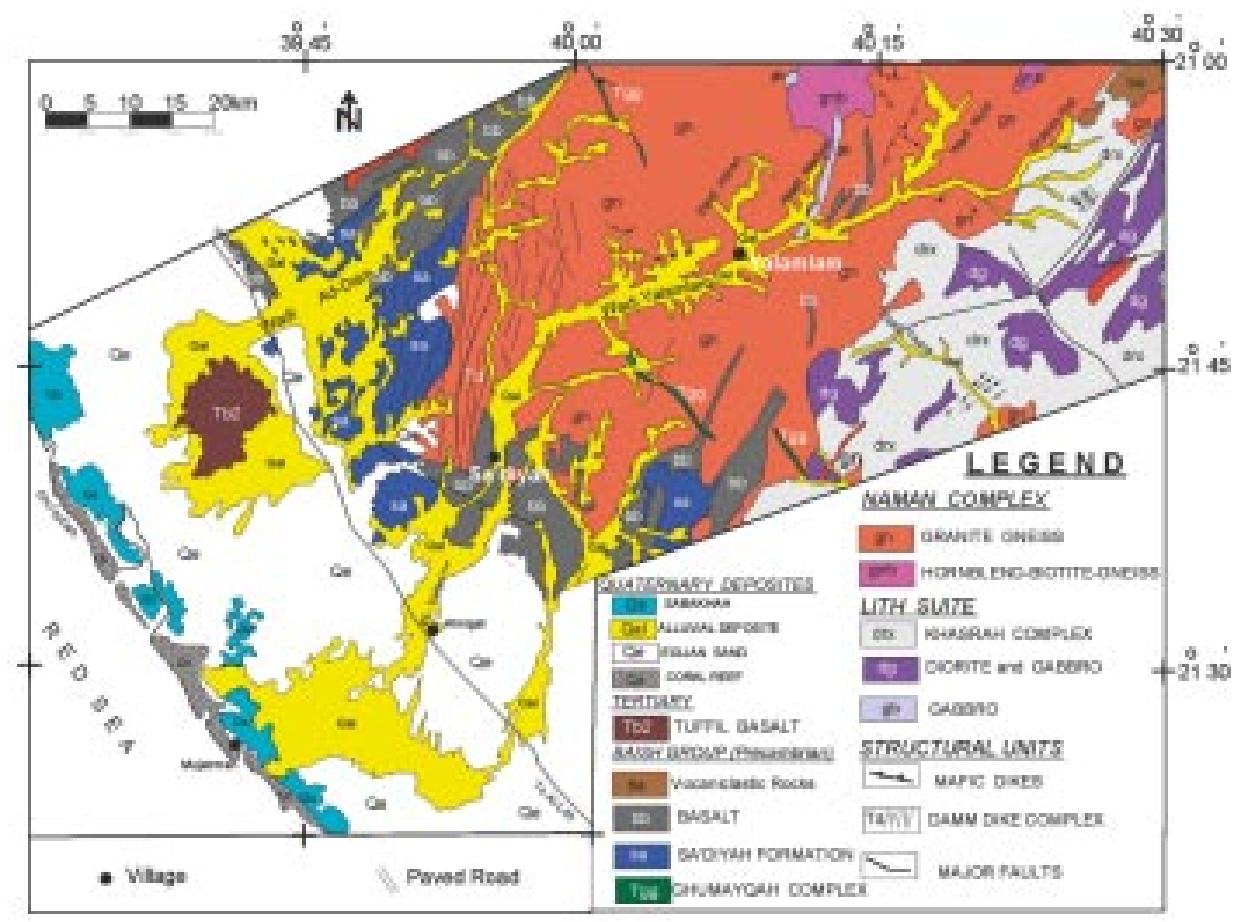

FIG. 2. Geologic map of Wadi Yalamlam (adopted from Pallister, 1986; Johnson, 1998).

\section{Precambrian Rocks}

The oldest Sa'diyah formation consists of mainly metasedimentary rocks comprising quartizite, schist, marble and amphibolite. It is located in the southern part of the area. The Baish Group, which is believed to be the oldest metavolcanic sedimentary group, consists of greenschist to amphibolite-facies metamorphic rocks. This group is originally derived from basaltic to rhyolitic volcanic and hypabyssal rocks (Moore and Al-Rehaili, 1989). Lith suite regionally 
overlies the Baish Group along an intrusive or faulted contact. This suite contains quartz diorite, tonalite gneiss, gabbro (Khasrah Complex), granodiorite, quartz monzodiorite, and mafic dikes.

The middle and upper parts of Wadi Yalamlam is mainly drained through Naman complex, Fig. 2. This complex is a northeast-trending, elongated granite-gneiss batholith. Most of the Ashafa and Hada mountains belong to Naman complex. This batholith intrudes rocks of the oldest rock units.

\section{Tertiary Rocks}

The three main rock units of the Tertiary rocks of Wadi Yalamlam are the Ghumaiga, Damm and Harrat Taffil. The Ghumaiga complex consist of gabbro to monzonite gabbros and widely spaced rocks in the form of dikes intruding the metavolcanic and plutonic rocks. In the middle and downstream parts of Wadi Yalamlam, these dikes are mainly trending to the northwest, and cutting the Wadi in south of the Sa'diyah village, Fig. 2. This structure may affect the subsurface flow of water to the lower reaches of Wadi Yalamlam. Damm complex is composed of alkali basalts, hawaiite, trachyte, dacite, and rhyolite rocks. Most of the flows are parallel, mainly north-south trending. These flows are also predominant downstream of the main channel of Wadi Yalamlam, and they may affect the groundwater flow. Harrat Tuffil, which is alkali basalt is located north of the study area. The lava flows are nonvesicular to moderately vesicular and unconformably overly the Precambrian rocks.

\section{Quaternary Deposits}

Quaternary deposits in the study area are bounded and overlie the Precambrian rocks in the west of the study area. They are of continental origin on the alluvial plain, overlapped and mixed with marine rocks and soils in the coastal zone. The Quaternary deposits consist of alluvial sand and gravel, sabkhah soils, and coralline reef rocks (Al-Sayari and Zötel, 1978).

To the west of the study area, a highly irregular shape eolian sand-dune field and silt deposits cover a large part of the coastal plain. These eolian sands dominate the study area as a result of drought. The pediment deposits are composed of poorly sorted, locally derived sand, silt and gravel.

Alluvial deposits comprise the largest Quaternary unit in the study area. They comprise unconsolidated sand, silt, and gravel and are deposited in the Wadi channels and outwashed plains. They also occur as terrace deposits along Wadi Yalamlam. The average thickness of these deposits increases from the upstream of the Wadi ( 2 meters) to the downstream areas near the main coastal road (more than 30 meters). 
Sabkhah soils are found as calcareous, gypsifereous, and saline silt, clay and sandy mud. This unit is found in immediate contact with the sea in a form of a narrow strip extending less than $3 \mathrm{~km}$ east of the coastline. It was deposited in a marine environment.

\section{Structural Geology of the Area}

The recent geological studies have shown that the Arabian Shield has been affected by orogenic episodes and a younger major faulting system. These uplift and faulting have resulted in steep escarpment facing down with torrents such as in deep valleys and then flow more slowly across the coastal plain, and frequently reach the Red Sea. During the Tertiary time, Damm faults were emplaced along the north-western margin of the study area, with north-west trend. Ghumayqah complex, which consists of widely spaced gabbroic dikes, intrude the metavolcanic rocks. These dikes are mainly trending toward the northwest, and cutting the Wadi south of Sa'diyah village, Fig. 2.

Another faulting event occurred during the Oligocene and Miocene which gave rise to the formation of the Red Sea Graben. The northwest-trending Quaternary faults are in the form of concealed fault system parallel to Red Sea, which are related to Shua'iba fault. This fault has resulted in the formation of the sabkhas and extensive alluvial in the lower course of the Wadi.

\section{Physiographical Setting}

The physiographical setting of Wadi Yalamlam basin can be divided into three main zones: the Red Sea coastal plain (Tihamah), the hills, and the ScarpHijaz Mountains, Fig. 3. The Red Sea coastal plain (Tihamah) is a flat strip of land located in the southwest of the study area, and bounded inland by the hills and seaward by the shelf area. It has a width of about $30 \mathrm{~km}$. The western portion of Tihamah is a depositional surface, principally a coral-reef and sabakhah deposits, while inland towards the foothills, it consists of alluvial deposits and eolian sands (floodplain) (Alsayari and Zötl, 1978). The elevation of Tihamah varies from sea level to 500 meters above sea level (m.a.s.l).

The hills area is a vast peneplain sloping slightly to the west of the Scarp Mountains. It consists mainly of Precambrian basement complex rocks. The elevation of the these hills varies from 200 to 1000 m.a.s.1.

The Scarp-Hijaz Mountains belt is characterized by knife-edge ridges and deep canyons.These high relief mountains are mainly located in Ashafa area, such as Judah and Dakah mountains where the Wadi starts. The elevation increases from 1500 to 2500 m.a.s.l. 


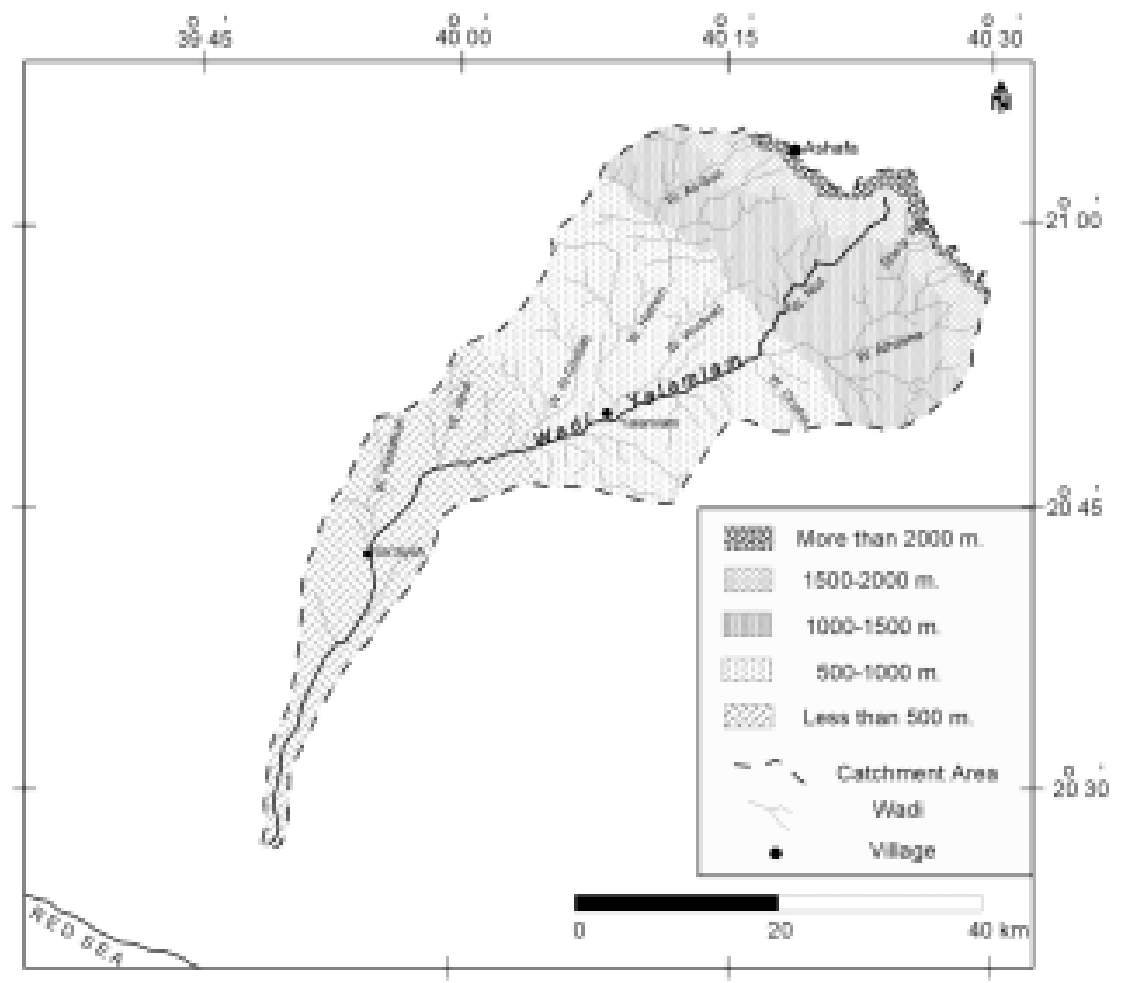

Fig. 3. Topographic map of Wadi Yalamlam.

Topography plays an important role in the distribution and flux of water and energy within the natural basin; these include surface water, evaporation, infiltration, heat exchange and other ground-atmosphere interface processes. The quantitative assessment of these processes depend on the topographic configuration of the basin.

\section{Morphometric Analysis}

The shape of the stream network reflects the hydrologic processes that prevail in the area and in turn determines the potential efficiency of the basin. The network characteristics also strongly reflect the climate, lithology, topography, and the geologic structure of the basin. Due to the unavailability of the Digital Elevation Model (DEM) for Yalamlam basin, the drainage network of the basin has been defined and mapped from Satellite images and topographic map (Arial Survey Department, 1982, scale 1:250,000). A variety of topological and geometric attributes have been measured such as drainage length, perimeter, and drainage area by using a digitizer. Other features such as drainage density, relief ratio, circularity and elongation, etc. are manipulated from maps and images . 


\section{Morphometric Features}

Different morphometric features have been defined for the drainage network (Strahler, 1952; Doornkamp and King, 1971; Gregory and Walling, 1973; and Maidment, 1993). These features are as follows:

i) The total channel length $\left(C_{t}\right)$, which is the summation of the lengths of all streams. $C_{t}$ was measured by the digitizer.

ii) The main stream length $\left(C_{m}\right)$ is measured by digitizer from Ashafa area to the mouth of the Wadi.

iii) The basin Length $\left(L_{b}\right)$ represents the most distant point.

iv) The basin perimeter $\left(P_{b}\right)$ and basin area $(A)$ were also measured by Didger software.

v) Drainage density $\left(D_{d}\right)$ for the basin was found by dividing the total length by the area of the basin as

$$
D_{d}=C t / A
$$

The drainage density is a very important variable that explains the climatological, geologic, and topographic features of the basin. It affects the basin discharge and potential.

vi) Relief $\left(H_{b}\right)$ is defined as the maximum elevation point where the main stream starts (Ashafa mountains).

vii) Relief Ratio $(R)$ is found by dividing the relief by the basin length as

$$
R=H_{b} / L_{b}
$$

Low value of relief ratio means that the host rocks are more resistant to physical geological processes.

viii) Elongation $(E)$ is defined as

$$
E=A^{0.5} / L_{b}
$$

If $E$ is smaller than 1.0, indicated that the basins is more elongated

ix) Circularity $\left(E_{c}\right)$ is defined as the ratio of the basin area to that of a circle, with the same perimeter as the basin; as

$$
E_{c}=A /\left(P_{b}^{2} / 4 \pi\right)
$$

If the Circularity is near to one, the basin is of circular shape.

x) Stream Order: There are many definitions for stream orders (Horton, 1945; Strahler 1952). Strahler system was used in this research. In this system all streams which have no tributaries are known as first-order streams. When two first-order streams are joined together, they form a second-order stream, and so on. The upper stream network of Yalamlam basin is denser starting from high steep slopes of Ashafa mountainous ridge. The middle and downstream 
networks of the basin are lighter due to low relief. In general, Yalamlam basin has the fourth-order stream, which means that the basin have a moderate potential of discharge.

xii) Drainage Patterns: There are many encountered drainage patterns such as dendritic, trellis, barbed, rectangular. These patterns are mainly affected by the rock types, structure, weathering, and rainfall intensity. A network streams of the Yalamlam basin is characterized by irregular branching of tributary streams in different directions. The host rocks are mainly composed of massive igneous rocks with a complexity of metamorphic rocks, which are very resistant. These features have resulted in a dendritic pattern.

Table 1 summarizes the different morphometric features of Yalamlam basin. It shows that the basin is very elongated, has high relief, and of a moderate drainage density (i.e. 434 meter per square kilometer). It has low stream flow discharge due to surface roughness and low rainfall intensity in the middle and lower parts of the basin. Fig. 4 shows the stream network of Yalamlam basin.

TABLE 1. Wadi Yalamlam basin morphometric characteristics.

\begin{tabular}{|l|c|}
\hline \multicolumn{1}{|c|}{ Variable } & Value \\
\hline Total length $\left(C_{t}\right)$ & $680 \mathrm{~km}$ \\
\hline Main stream length $\left(C_{m}\right)$ & $105 \mathrm{~km}$ \\
\hline Basin length $\left(L_{b}\right)$ & $94 \mathrm{~km}$ \\
\hline Basin perimeter $\left(P_{b}\right)$ & $243 \mathrm{~km}$ \\
\hline Basin area $(A)$ & $1610 \mathrm{~km}^{2}$ \\
\hline Drainage density $\left(D_{d}\right)$ & $0.434 \mathrm{~km}^{-1}$ \\
\hline Relief $\left(H_{b}\right)$ & $1500 \mathrm{~m}$ \\
\hline Relief ratio $(R)$ & $17 \mathrm{~m} / \mathrm{km}$ \\
\hline Elongation $(E)$ & 0.43 \\
\hline Circularity $\left(E_{c}\right)$ & 0.34 \\
\hline
\end{tabular}

\section{Hydrological Setting}

One of the main targets is the study of water resources in Wadi Yalamlam basin, and the identification of major factors affecting the magnitude and distribution of rainfall, such as altitude, various air mass movement, distance from the source moisture, temperature and pressure, and topography of the basin. In arid regions, the magnitude and distribution of precipitation vary from place to 
place and from time to time, even in small areas. Describing and predicting the rainfall variability in space and/or time are fundamental requirements for a wide variety of human activities and designing water projects.

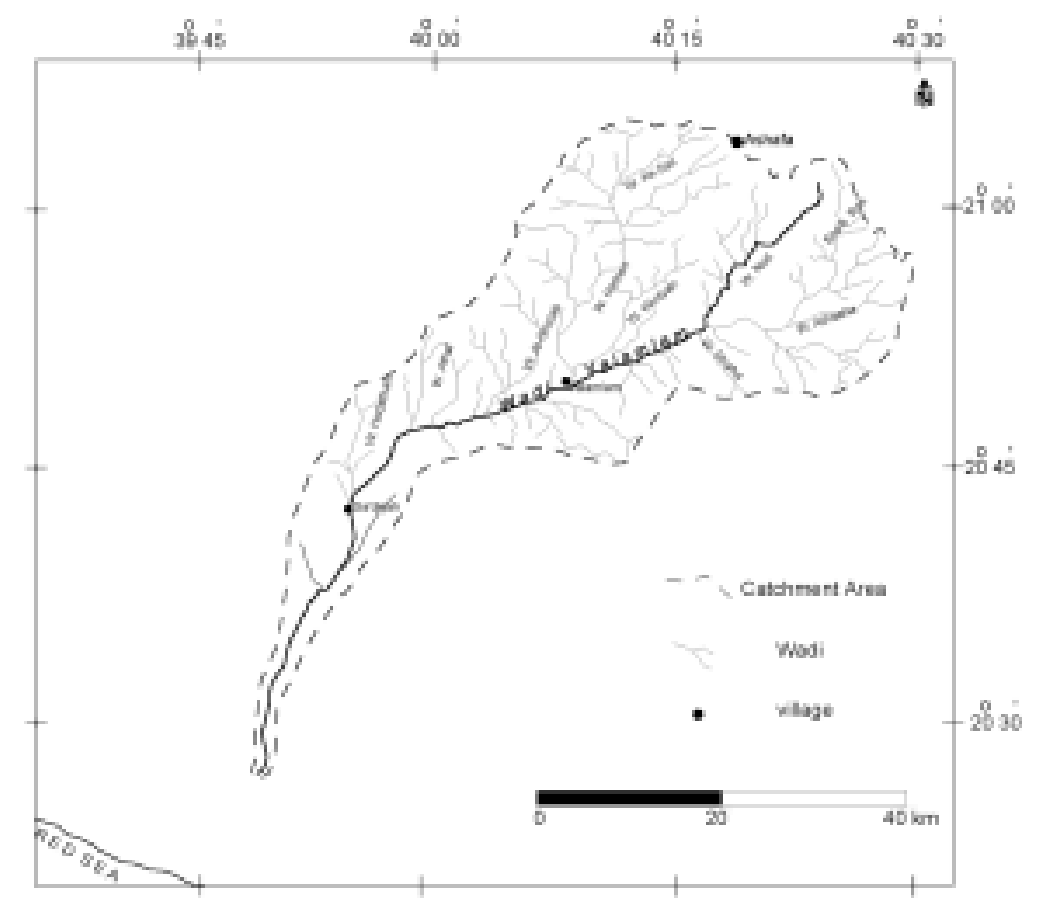

FIG. 4. Drainage pattern of the Wadi Yalamlam basin with stream network. Adopted from topographic map ) Arial Survey Dept, 1978, 1:250,000 scale).

In Saudi Arabia, rainfall can be described as very little and unpredictable as well as irregular, but very extensive during local storms. The rate of evaporation is very high. In addition, there are no perennial streams. Wadi Yalamlam receives a high amount of rainfall compared to other basins, because it is mostly located in the mountains and belong to the subtropical zone. Intermittent streams exist in the upper reaches of Wadi Yalamlam, such as those flowing immediately upstream of Yalamlam village.

Since 1970 's, a network of climatological and surface runoff stations have been established for the preliminary assessment of water resources data around the study area. A number of studies have been conducted by various consulting firms working on behalf of the Ministry of Agriculture and Water (MAW) on various aspects of water resources, such as hydrology and agriculture. Sogreah (1968), German Consult (1979), and Saudi Arabian Dames and Moore (1988) studied most of the Wadis in western and southwestern regions of the Arabian 
Shield and Tihamah in Saudi Arabia for water resources and agriculture development. Other research for these Wadis include those conducted by researches such as Hussien (1985); Sadhan (1980); Jamaan (1978); Alehaideb (1985); Sorman et al. (1991).

\section{Climate Conditions Over the Western Province}

The climate pattern over the western province can be described by considering the various air masses that affect the rainfall distribution over the area considered. The influence of the various air masses and the rainfall pattern over the Kingdom are discussed and mapped by several investigators (McLaren, 1979; Şen, 1983; and Alyamani and Şen, 1992).

Air masses, which have an influence on the Kingdom's climate, show that there are three major fronts of moisture flowing into the Kingdom.

1) The monsoon front during the late fall and summer (maritime tropical air mass) that reaches the area from south, southwest, and southeast. This front originates from the Indian Ocean and Arabian Sea and brings the warm and moist air. Outbreaks of westerly air become more frequent and are characterized by medium to high intensity of rainfall over the south and southwest of the country. This front often picks up further moisture while moving through the Red Sea trough.

2) The continental tropical air masses, which are warm and moist coming from the Atlantic Ocean through the middle and north African continent.

3) The maritime polar air masses derived from the eastern Mediterranean Sea. At early winters the Mediterranean-born maritime air increasingly disturbs the monsoonal air movement and displaces it in the low altitude.

Generally, these maritime depressions draw the tropical continental air masses into warm sectors and generate extreme weather conditions. Both the continental tropical and maritime polar air masses move toward the east and prevail in winter. During winter, (December-February), precipitation is associated usually with weak influxes of moist cold air of westerly Mediterranean origin which is coupled with the local effects of the Red Sea and Scarp, where the rainfall occurs orographically. During spring (March-May), the intertropical front starts to move northwards, and the region comes under the influence of a relatively moist southeasterly air monsoon stream flow, which give rise to rainfall along the leeward side of the mountains and the Red Sea coast. During summer (June-August), monsoons condition, creating thunderstorms along the escarpment and the southern part of the Red Sea coast, are predominant. During fall (September-November), the southeasterly air stream weakens as a result of increasing outbreaks of northwesterly air stream. This phenomena sometimes causes a strong convergence and gives way to tropical winter conditions and widespread rainfall, (Şen, 1983; Alehaideb, 1985). 


\section{Climate in Yalamlam Basin}

Yalamlam basin is affected by the high pressure of the subtropical zone in addition to the local topography. Both the regional and local circulation have a dominant influence on the climate of the region. According to the world climate classification established by Koppen (Glenn, 1954), Yalamlam basin can be divided into three main climate types: 1) the hot desert climate that prevails on the Red Sea coast (Tihamah), 2) the low latitude semi-arid climate that prevails in the hills, and 3) the warm temperate rainy climate with dry winters that prevails in the Scarp Mountains (Taha et al., 1981).

On the Red Sea coast, there are two basic climates: cool to warm and stable air originating from the Mediterranean during the winter period, and warm and moist air due to monsoons coming from the Indian Ocean during summer. From the temperature records in the Red Sea coast stations, the mean monthly maximum temperature is $38^{\circ} \mathrm{C}$ and the mean monthly minimum temperature is $20^{\circ} \mathrm{C}$. The highest recorded temperature in July is $49^{\circ} \mathrm{C}$ and the lowest in January is $12^{\circ} \mathrm{C}$. The maximum mean monthly evaporation value is around $500 \mathrm{~mm}$ in summer, where in winter it is about $200 \mathrm{~mm}$.

The climate of the hills is generally characterized as mild with some rains in winter and spring, and hot and dry in summer and fall. The mean monthly maximum temperature is $30^{\circ} \mathrm{C}$ and the mean monthly minimum temperature is $15^{\circ} \mathrm{C}$. The highest temperature recorded in July is $38^{\circ} \mathrm{C}$ and the lowest in January is $8^{\circ} \mathrm{C}$.

The Scarp Mountains (Ashafa area), which are characterized by high altitude, tend to have a lower annual range of temperature than the surrounding low areas. The mean minimum temperature is as low as $0^{\circ} \mathrm{C}$ in scattered locations, especially in high peaks in winter. The mean maximum temperature is $25^{\circ} \mathrm{C}$ in summer. The maximum monthly mean evaporation value is around 500 $\mathrm{mm}$ in summer, where in winter it is about $200 \mathrm{~mm}$ (El-Khatib, 1980).

\section{Rainfall}

Over the study area, rainfall occurs every season of the year but varies from year to year. Due to the topographic conditions, rainfall distribution varies in space as well as in time. The rainfall often occurs as thunderstorms of very high intensity during a local storm followed by dry periods. Fall rainfall is related to local diurnal circulation, summer rainfalls to the monsoons, and winter and spring rainfalls to the African-Mediterranean interaction. Generally, rainfall in the study area takes place due to the influence of subtropical and orographic conditions. In order to assess groundwater conditions and the recharge within the basin, it is necessary to define the predominant climate patterns that have an influence on rainfall distribution over the basin. 


\section{Annual and Seasonal Rainfall Distribution}

The climatological data used in this project were collected from the hydrology division of the Ministry of Agriculture and Water in Riyadh and Aljerash (1989). The meteorological data of Yalamlam basin which consist of rainfall, relative humidity, evaporation, and air temperature are in monthly means. Unfortunately, some of the stations in the Yalamlam basin such as Sa'diyah (1 year) and Mujairmah (4 years) have very short records of the rainfall, while other stations are lumped in the mountains, such as Ashafa, Taif, Hada, and Jarmooz. The overall available rainfall records cover a period ranging from 15 to 25 years. From scientific point of view and for unbiased spatially distribution of climatological stations, some stations with long enough records of rainfall were chosen, such as Alith, Ghomaiga, Adham, Jermuz, Ashafa, Wadi Muhrem, and Firran as shown in Table 5.

TABLE 2. Mean annual and seasonal rainfall around Yalamlam basin.

\begin{tabular}{|l|l|r|l|r|r|r|r|r|c|}
\hline $\begin{array}{c}\text { Station } \\
\text { code }\end{array}$ & \multicolumn{1}{|c|}{$\begin{array}{c}\text { Station } \\
\text { name }\end{array}$} & Longitude & Latitude & $\begin{array}{c}\text { Altitude } \\
(\mathrm{meter})\end{array}$ & $\begin{array}{c}\text { Annual } \\
(\mathrm{mm})\end{array}$ & $\begin{array}{c}\text { Winter } \\
(\mathrm{mm})\end{array}$ & $\begin{array}{c}\text { Spring } \\
(\mathrm{mm})\end{array}$ & $\begin{array}{c}\text { Summer } \\
(\mathrm{mm})\end{array}$ & $\begin{array}{c}\text { Fall } \\
(\mathrm{mm})\end{array}$ \\
\hline J138 & Adham & 202900 & 405500 & 400 & 325 & 112 & 128 & 31 & 54 \\
\hline J113 & Firrain & 212200 & 400700 & 520 & 180 & 48 & 49 & 7 & 74 \\
\hline Ta106 & W. Muhrem & 212000 & 401900 & 1870 & 188 & 36.5 & 89 & 13 & 49.3 \\
\hline 10 & Ashafa & 210400 & 402200 & 2130 & 260 & 60 & 100 & 36 & 63 \\
\hline TA218 & Jermuz & 210400 & 403100 & 1820 & 180 & 45 & 90 & 11 & 34 \\
\hline J108 & Lith & 200900 & 401700 & 6 & 89 & 40 & 11 & 1 & 36.6 \\
\hline J107 & Ghomaiga & 201900 & 402700 & 90 & 81 & 39.2 & 12.3 & 5.3 & 24.3 \\
\hline
\end{tabular}

The map of mean annual rainfall distribution is presented in Fig. 5. This figure reflects the topographic effect on the rainfall .

Generally, rainfall is predominant in the northern mountain areas during winter due to the Mediterranean effect, while it is widespread in all regions during spring because of the local diurnal circulation effect. Orographic conditions are clear in winter and spring seasons. In summer, precipitation moves towards the south due to the monsoon flow effect with its south-westerly wind. In fall, the area becomes under the influence of monsoon as well as the local diurnal circulation. Fig. 6-9 illustrate these spatioseasonal variations of precipitation in the study area. Winter and spring rainfall are significant for groundwater recharge due to low actual evaporation and low temperature, whereas the high percentage of fall rainfall evaporates due to high temperature and evaporation. 


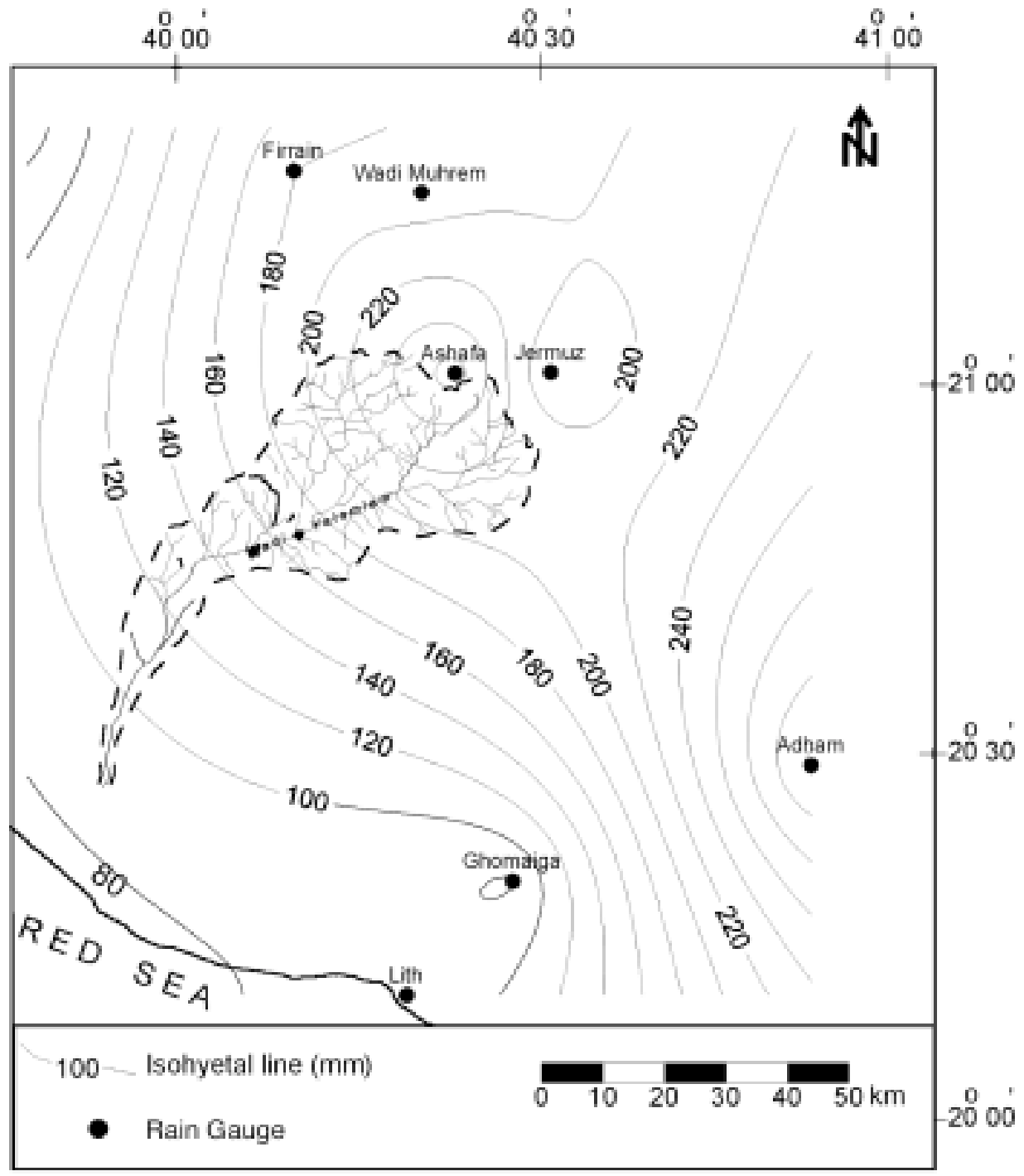

FIG. 5. Mean annual rainfall distribution over Yalamlam basin. 


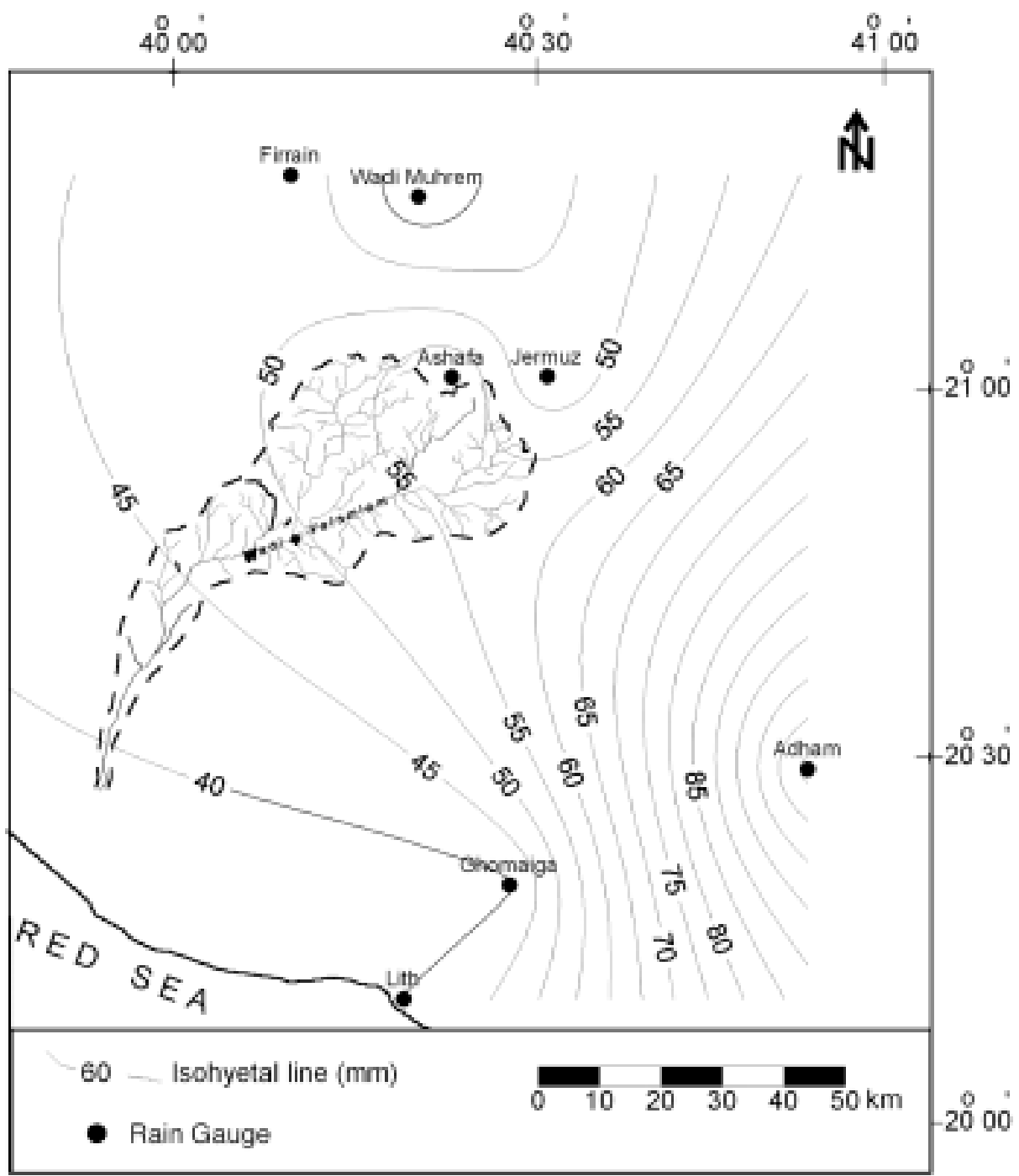

FIG. 6. Winter rainfall distribution over Yalamlam basin. 


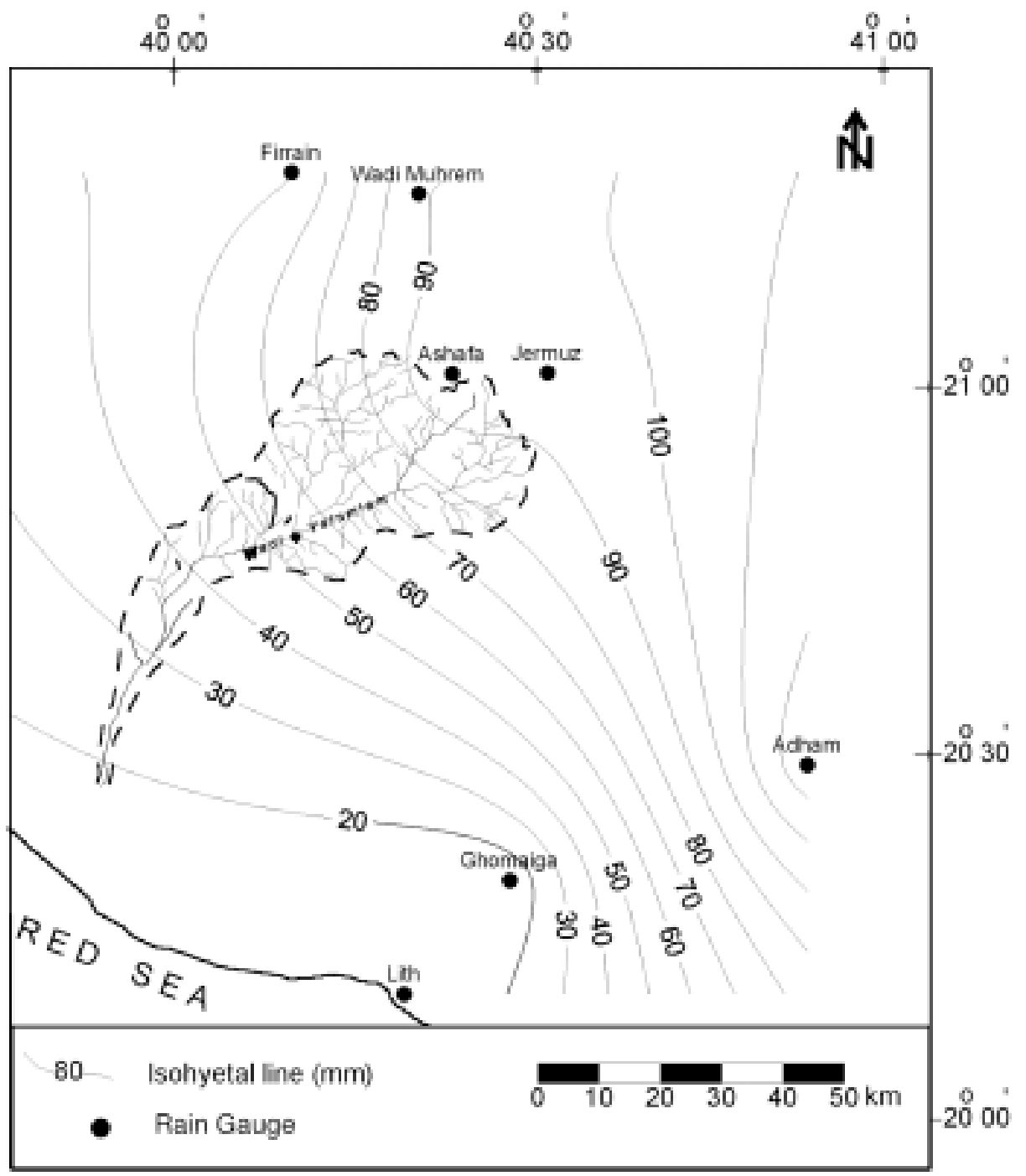

FIG. 7. Spring rainfall distribution over Yalamlam basin. 


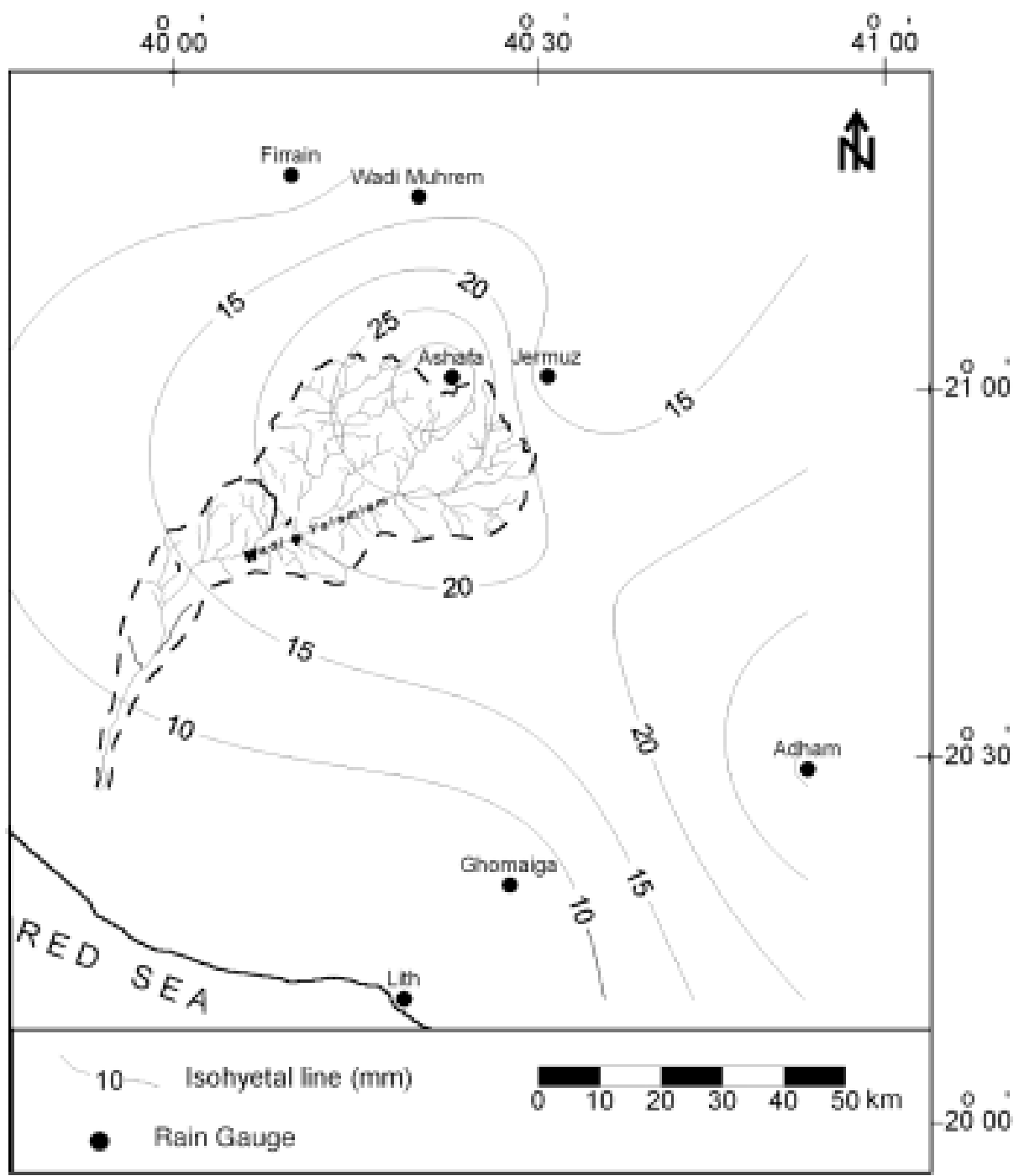

FIG. 8. Summer rainfall distribution over Yalamlam basin. 


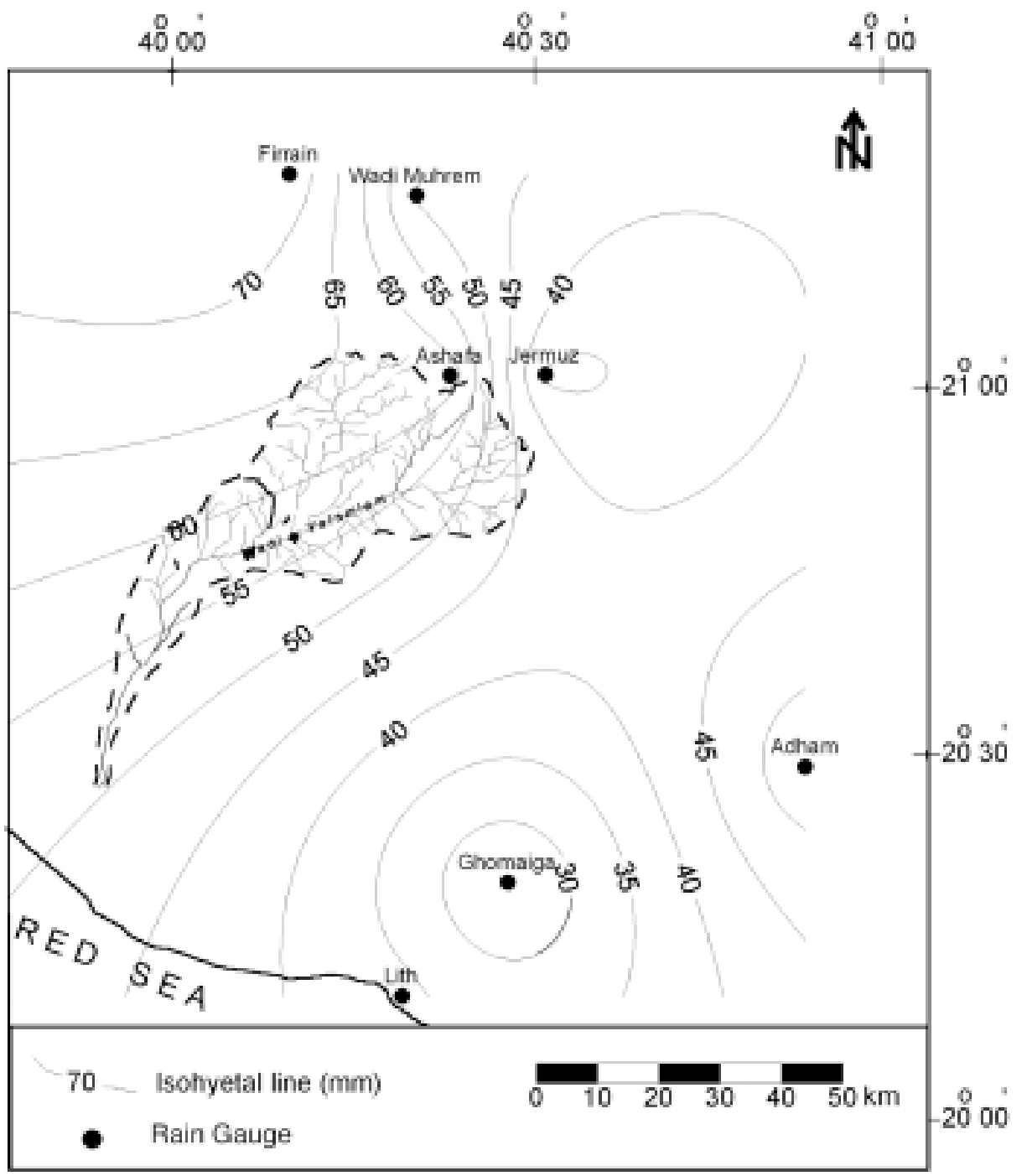

FIG. 9. Fall rainfall distribution over Yalamlam basin. 


\section{Flood Discharge Measurements}

One of the most important factors in groundwater recharge studies is to define the hydraulic response of the wadi basin. This includes peak discharge, lag time, base time, and time concentration.

Various methods are available for estimating the peak rates of runoff required for design application in small urban and rural watersheds. Some incorporate a rational analysis of the rainfall-runoff process, others are completely based on drainage basin characteristics, whereas others are based on the probability theory by using the previous known flood data.

The satellite images show that Wadi Yalamlam stream flow is generally intermittent in the areas immediately upstream of Yalamlam village. Basic runoff and rainfall data are not available to allow construction of a unit hydrograph, therefore, techniques have evolved that allow generation of synthetic unit hydrograph. Such methods can be applied for areas based on known physical properties of the basin. Among several formulae that have been devised for the purpose of estimating the peak discharge, Snyder method was selected in the present work (Show et al., 1988 and Wanielista et al., 1997).

\section{Snyder Method}

This method has been commonly used to derive synthetic hydrograph for several areas. In this method, it is necessary to know the time of peak discharge, time base and peak discharge. These elements should be determined for every local or regional drainage basin. Snyder proposed the following empirical formulae:

$$
T_{1}=C_{t}\left(L . L_{c}\right)^{0.3}
$$

Where $T_{1}=$ the lag time (hr).

$C_{t}=$ a coefficient representing variations of watershed slope and storage; it ranges from 1.8-2.2.

$L=$ length of the main stream channel from the outlet to the divide line $(\mathrm{km})$.

$L_{c}=$ length from the outlet to a point on the stream nearest to the centroid of the basin $(\mathrm{km})$.

For a standard duration of rainfall, Snyder proposed the following equation:

$$
T_{r}=T_{1} / 5.5
$$

Where $T_{r}=$ duration of the unit rainfall (hr).

For any desired duration, the following formula should be used 


$$
T_{1 R}=T_{1}+0.25\left(T_{R}-T_{r}\right)
$$

Where $T_{1 R}=$ the adjusted lag time (hr).

$T_{R}=$ the desired unit hydrograph duration (hr).

$T_{1}$ and $T_{r}$ as defined in Eqs. 1 and 2.

The peak discharge can be estimated from the following formula:

$$
Q_{p}=\left(C_{p}{ }^{*} A\right) / T_{1 R}
$$

Where $Q_{p}=$ the peak discharge $\left(\mathrm{m}^{3} / \mathrm{s}\right)$.

$C_{p}=$ a coefficient ranging from 4 to 5 (larger value of $C_{p}$ is generally associated with smaller $C_{t}$ ).

$A=$ the drainage area $\left(\mathrm{km}^{2}\right)$.

On the other hand, the time base, can be calculated by the following formula:

$$
T_{b}=3+\left(T_{1} / 8\right)
$$

After obtaining the value of peak or flood discharge $\left(Q_{p}\right)$ by Snyder method, the synthetic unit hydrographs, method which has been developed by the Soil Conservation Service (SCS), was adopted in the present work. The method is a result of an analysis of a large number of natural unit hydrographs from a wide range of sizes and geographic locations. The method requires only the determination of the time to peak and the peak discharge. Further discussion on these above techniques are available in text books, e.g. (Viessman et al., 1989; and Linsley et al., 1982).

Based on the above mentioned methods, the hydraulic responses have been determined for three sub-basins of Wadi Yalamlam. These wadis are Hethan (Area I), and Niat (Area II), and Yalamlam (Area III) as shown in Fig. 10. The hydraulic response of each wadi assumes that rainy storms cover the entire area, that could contribute to the studied wadi. Runoff hydrographs of 0.5 hour duration were constructed. The results obtained are shown in Table 3, while the hydrographs are illustrated in Fig. 11 and 12.

\section{Conclusion}

Wadi Yalamlam is one of the undeveloped major Wadis in Makkah AlMukarramah area. It drains a wide catchment area of about $1600 \mathrm{~km}^{2}$. The catchment area starts from the Hijaz Escarpment (Ashafa area) in the east to the Red Sea in the west. The geological and geographical setting of Wadi Yalamlam basin can be divided into three main zones: the Red Sea coastal plain (Tihamah), the hills, and the Scarp-Hijaz Mountains. These features reflect the topographic and morphometric situations in addition to the human population and activities in the area. 


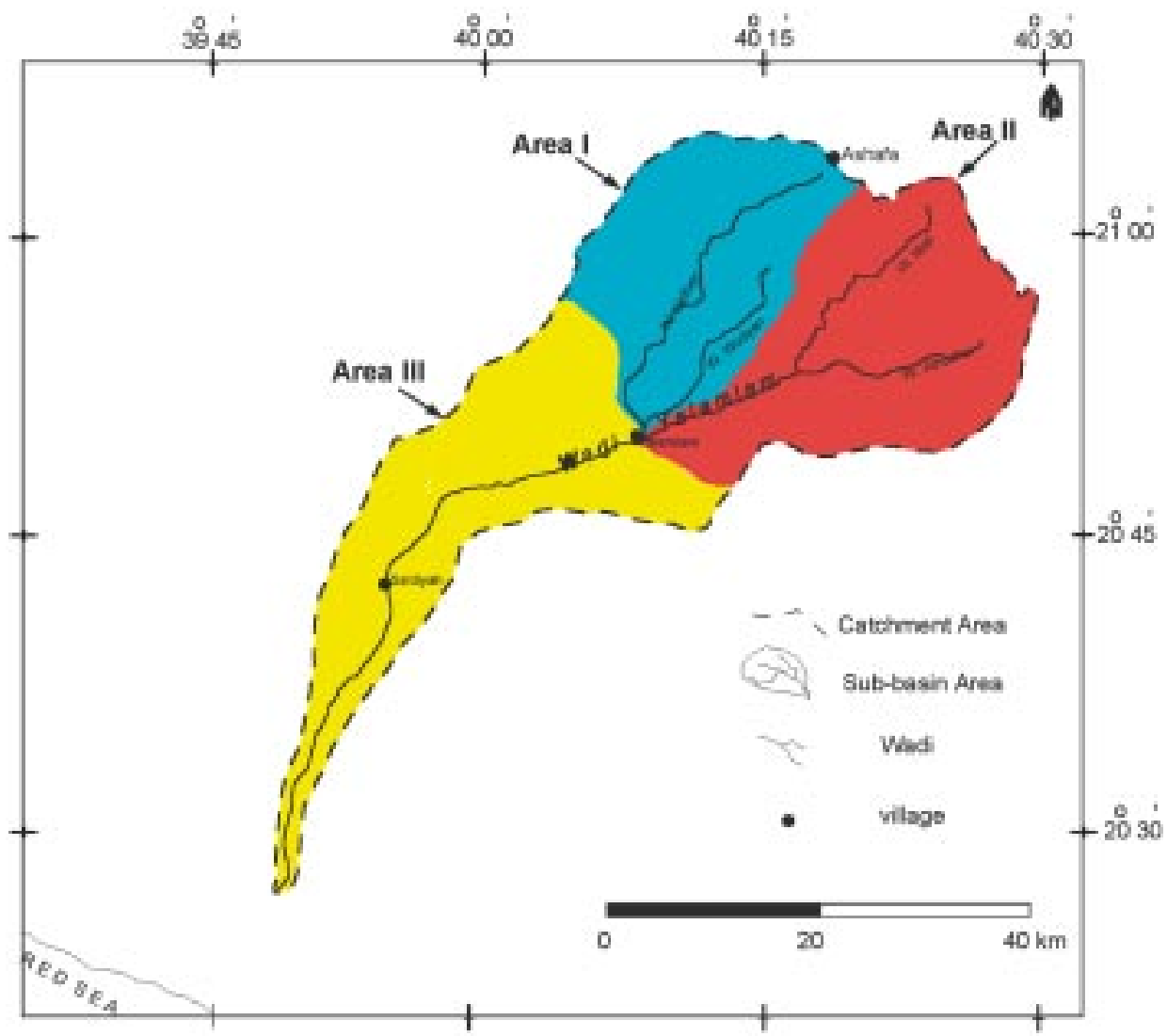

Fig. 10. Three sub-basin of Wadi Yalamlam.

TABLE 3. Flood peaks and volumes with 0.5 hour duration (Snyder method).

\begin{tabular}{|l|c|c|c|c|c|c|c|}
\hline Sector & $\begin{array}{c}L \\
(\mathrm{~km})\end{array}$ & $\begin{array}{c}L_{c} \\
(\mathrm{~km})\end{array}$ & $\begin{array}{c}\text { Drainage area } \\
\left(\mathrm{km}^{2}\right)\end{array}$ & $\begin{array}{c}\text { Peak discharge } \\
\left(\mathrm{m}^{3} / \mathrm{s}\right)\end{array}$ & $\begin{array}{c}\text { Lag time } \\
(\mathrm{hr})\end{array}$ & $\begin{array}{c}\text { Time base } \\
(\text { day })\end{array}$ & $\begin{array}{c}\text { Volume } \\
\mathrm{X} 10^{6} \mathrm{~m}^{3}\end{array}$ \\
\hline Area I & 34.4 & 16.9 & 610 & 260.2 & 11.72 & 4.52 & 5.4 \\
\hline Area II & 36.9 & 18.8 & 370 & 168.5 & 10.98 & 4.60 & 3.5 \\
\hline Area III & 56.3 & 28.1 & 635 & 201.1 & 15.79 & 5.05 & 4.1 \\
\hline $\begin{array}{c}\text { Wadi } \\
\text { Yalamlam }\end{array}$ & 94 & 47 & 1610 & 376 & 21.4 & 5.79 & 7.7 \\
\hline
\end{tabular}




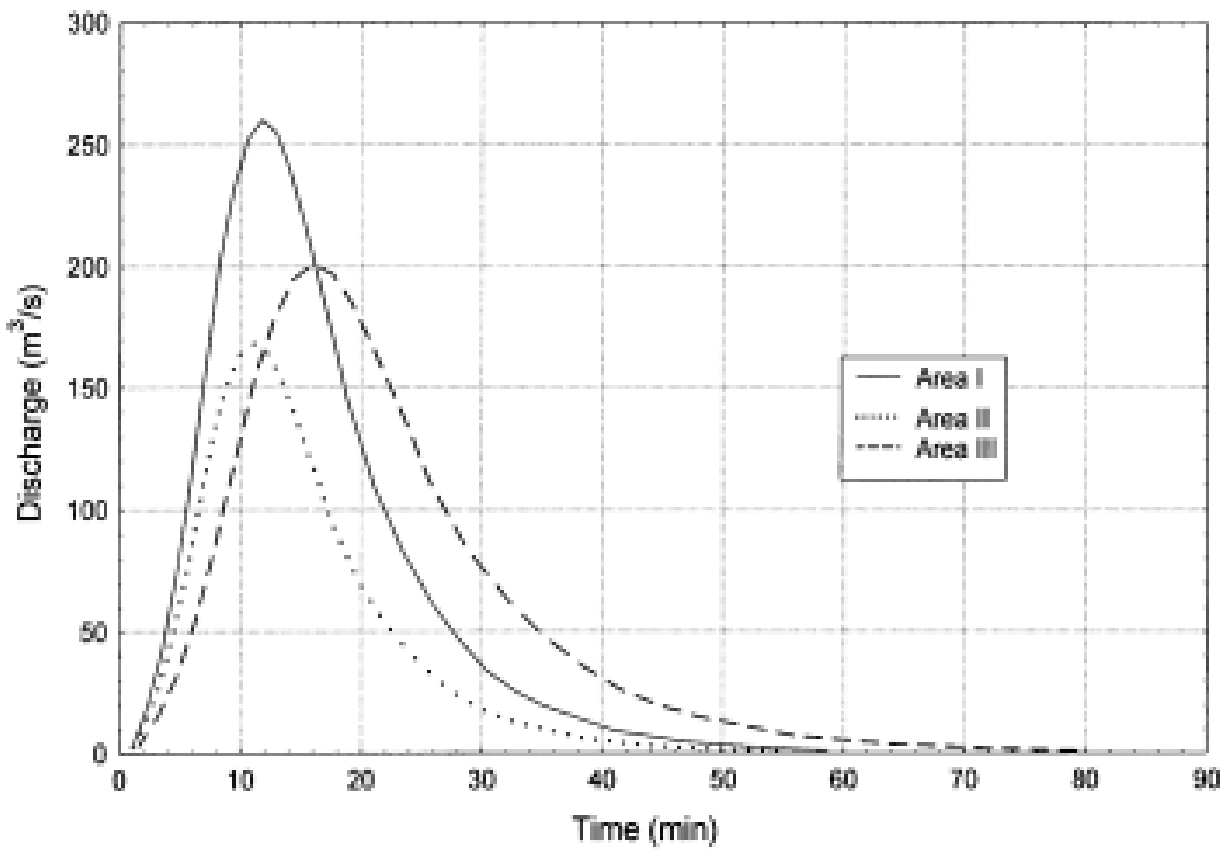

FIG. 11. Synthetic hydrographs for Yalamlam sub-basins (SCS method).

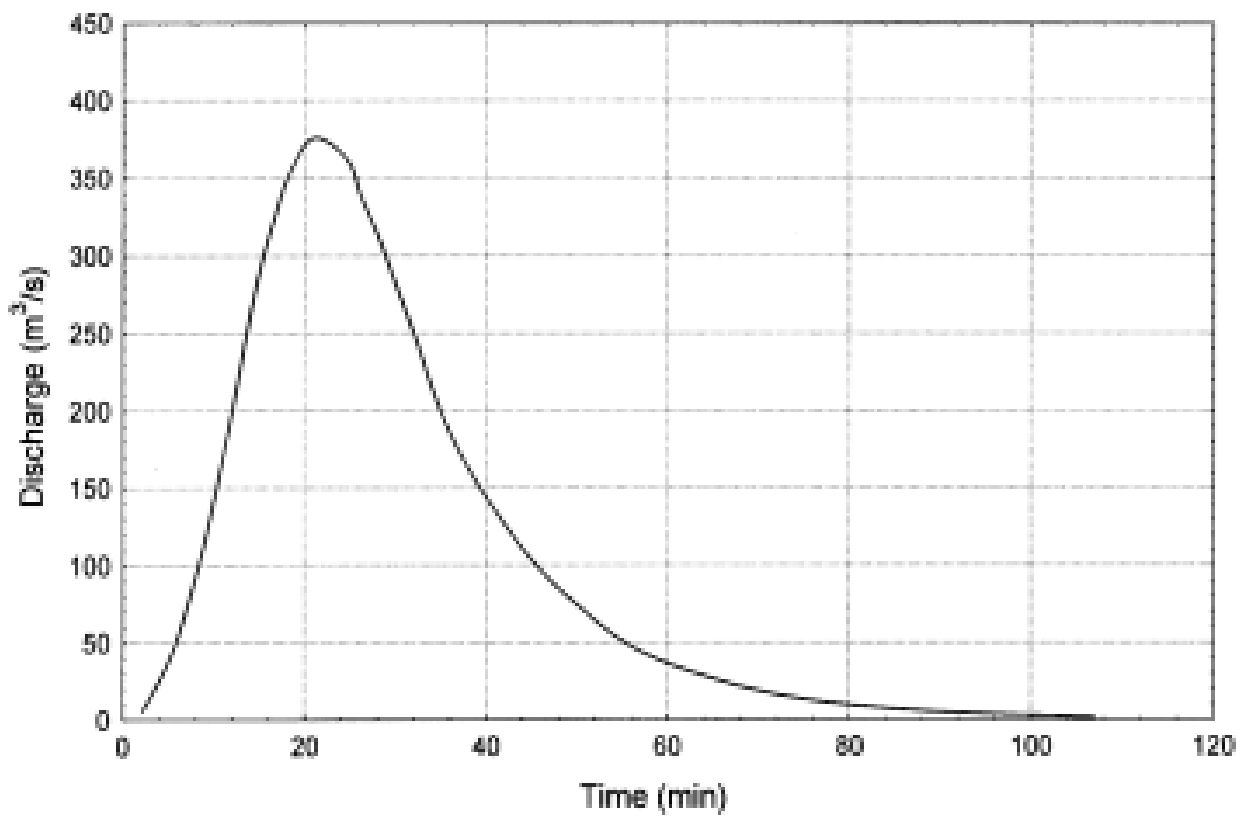

FIG. 12. Synthetic hydrograph for Yalamlam basin (SCS method). 
A variety of topological and geometric attributes of the stream network for Yalamlam basin have been measured by using morphometric features. The study shows that the basin is very elongated and has high relief and moderate drainage density (i.e. 434 meter per square kilometer). It also has low stream flow discharge due to surface roughness and low rainfall intensity in the middle and lower parts of the basin.

Climate in Yalamlam basin is affected by the high pressure of the subtropical zone in addition to the local topography. Both regional and local circulations have dominant influence on the climate of the region. Yalamlam basin can be divided into three main climate types: 1) the hot desert climate that prevails in Tihamah; 2) the low latitude semi-arid climate that prevails in the hills; and 3) the warm temperate rainy climate with dry winters that prevails in the Scarp Mountains.

Over the study area, rainfall occurs every season of the year in the mountains area, but varies from year to year. It often occurs as thunderstorms of high intensity during a local storm followed by dry periods. The average annual rainfall exceeds $200 \mathrm{~mm}$ in the mountains and decreases to $80 \mathrm{~mm}$. in the Red Sea coast. In addition, wadi Yalamlam has surface running water in the upstream most of the year. Peak discharge and volumes of runoff were calculated for three sub-basins using synthetic hydrographs of 0.5 hour duration, based on Snyder method, for the study area.

\section{Acknowledgement}

The authors wish to express their deep gratitude to the Scientific Research Council of King Abdulaziz University for the financial support of this project (203/420). The comments of the reviewers are gratefully acknowledged.

\section{References}

Alehaideb, I. (1985) Precipitation Distribution in the Southwest of Saudi Arabia, Ph.D., Arizona State University, p. 215.

Aljerash, M.(1989) Data for Climatic Water Balance. Scientific Publishing Center, King Abdulaziz University, Jeddah, Saudi Arabia, p. 441.

Arial Survey Department (1978) Topographic Map of Wadi Yalamlam. Ministry of Petroleum and Mineral Resources, Riyadh, Kingdom of Saudi Arabia , 1:250,000 scale.

Alsayari, S. and Zötl, J. (1978) Quaternary Period in Saudi Arabia, Springer-Verlag, Wien, New York, p. 334.

Alshanti, A. (1993) Geology of the Arabian Shield (Arabic). King Abdulaziz University Publications, Jeddah, Saudi Arabia, p. 196.

Alyamani, M.S. and Şen, Z. (1992) Regional variation of monthly rainfall amounts in the Kingdom of Saudi Arabia. Jour. KAU: FES. 6: 113-133. 
Brown, G.F., Jackson, R.O., Bogue, R.G. and MacLean, W.H. (1963) Geology of the Southern Hijaz Quadrangle, Kingdom of Saudi Arabia. DGMR, Misc. Geologic Inves. Map I210A, 1:500,000 scale.

Doornkamp, J. and King, C. (1972) Numerical Analysis in Geomorphology, An Introduction. Edward Arnlond Publisher Ltd., London, p. 372.

El-Khatib, A. (1980) Seven Green Spikes, Ministry of Agriculture and Water, Riyadh, Saudi Arabia, p. 362.

German Consult (1979) Investigation and Detailed Studies for the Agricultural Development of South Tihama, Final Report and Preliminary Design for Ministry of Agriculture and Water, Riyadh, Saudi Arabia.

Glenn, T. (1954) An Introduction to Climate. McGraw-Hill, New York, 3rd ed.

Gregory, K.J. and Walling, D.E. (1973) Drainage Basin Form and Process, Arnold, London.

Hussein, J.A. (1892) Groundwater Recharge in Wadi Naaman and Fatimah, M.Sc Thesis, Faculty of Earth Sciences, King Abdulaziz University, Jeddah, Saudi Arabia, p. 267.

Horton, R.E. (1945) Erosional development of streams and their drainage basins: Hydrophysical Approaches to Quantitative Morphology, Geol. Soc. Am. Bull., 56: 275-370.

Jamaan, A. (1978) Hydrogeology of Wadi Naaman, M.Sc. Thesis, Institute of Applied Geology, Jeddah, Saudi Arabia, p. 250.

Johnson, P.(1998) Tectonic Map of Saudi Arabia and Adjacent Areas, Ministry of Petroleum and Mineral Resources: Deputy Ministry for Mineral Resources, Jeddah, Kingdom of Saudi Arabia, 1:4,000,000 scale.

Linsley, R.K., Kohler, M.A. and Paulhus, J.L. (1988) Hydrology for Engineers, Mc Graw-Hill Book Co., London, p. 492.

McLaren International Limited (1979) Water and Agricultural Developed Studies: Arabian Shield South. Hydrogeological Investigation, Annex 3. Ministry of Agriculture and Water, Riyadh, Saudi Arabia.

Maidment, R.D. (1993) Handbook of Hydrology. Chapter 3 and 11. McGraw-Hill Co. New York.

Moore, T.A. and Al-Rehaili, M.H. (1989) Geologic Map of Makkah Quadrangle, sheet 21D, Kingdom of Saudi Arabia: DGMR, Geoscience map GM-107C, 1:250,000 scale.

Noory, M. (1983) Water and the Progress of Development in the Kingdom of Saudi Arabia (Arabic). Tihama Publisher, Jeddah, Saudi Arabia, p. 302.

Pallister, J.S. (1986) Geologic map of Al-Lith Quadrangle, sheet 20D, Kingdom of Saudi Arabia: DGMR, Geoscience map GM-95, 1:250,000 scale.

Sadhan, A.S. (1980) Water plan for Wadi Fatimah basin, M.Sc. Thesis, University of Wyoming, Laramie. USA.

Saudi Arabian Dames and Moore (1988) Ministry of Agriculture and Water. Water resources development. Al-Lith Basin, Final Report. Vol. E.

Şen, Z. (1983) Hydrology of Saudi Arabia, Symposium on Water Resources in Saudi Arabia, Riyadh, pp. A68-A94.

Show, V.T., Maidment. D.R. and Mays, L.W. (1988) Applied Hydrology, McGraw-Hill Book Co., New York, p. 572.

Sogreah (1968) Water and Agricultural Development Survey for Area IV, Final Report, Ministry of Agriculture and Water, Riyadh, Saudi Arabia.

Şorman, A., Abdulrazzak, M.J. and Onder, H. (1991) Analysis of Maximum Flood Events and their Probability Functions Under Arid Climate Conditions in Saudi Arabia, International Hydrology and Water Resources Symposium, Perth.

Strahler, A.N. (1952) Dynamic Basis of Geomorphology, Geol. Soc. Am. Bull., 63: 923-938. 
Subyani, A. and Bayumi, T. (2001) Evaluation of Groundwater Resources in Wadi Yalamlam basin, Makkah Al-Mukarramah area. Project No. 203/420, King Abdulaziz Univ., Jeddah, Saudi Arabia, p.128.

Taha, M., Harb, S., Nagib, M. and Tantawy, A. (1981) The Climate of the Near East: in: The Climate of the Southern and Western Asia, by Takahashi and Arkawa (Ed). World Survey of Climatology, Elsevier Scientific Publications, New York, 9: 183-255.

Wanielista, M., Kersten, R. and Eaglin, R. (1977) Hydrology, Water Quantity and Quality Control, Second Ed., John Wiley and Sons, Inc, New York, p. 567.

Wier, K.L. and Hadley, D. (1975) Reconnaissance Geology of the Wadi Sa'diyah Quadrangle [20/40A]: U.S. Geological Survey Saudi Arabian Project Report PR-193, p. 27.

Viessman, W.Jr., Lewis, G.L. and Knapp, J.W. (1996) Introduction to Hydrology, 4th Ed., Harper Collins College Publishers, New York, p. 760. 


\section{تحليل الخصائص الطبيعية والهيدرولوجية لحوض وادي يلملم ، منطقه مكة المكرمة}

\section{علي محمد الصبياني و طارق حسن بيومي}

قسم جيولوجيا المياه ، كلية علوم الأرض ، جامعة الملك الكبان عبد العزيز

جـــــ - المملكة العربية السعودية الارضية

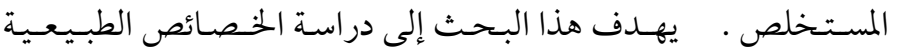

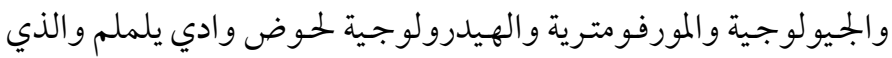

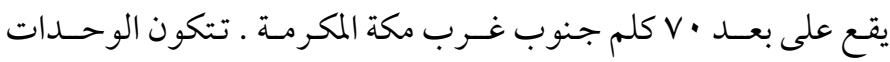

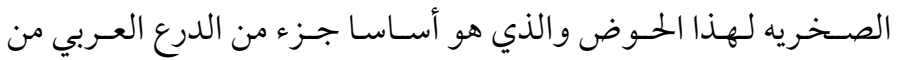

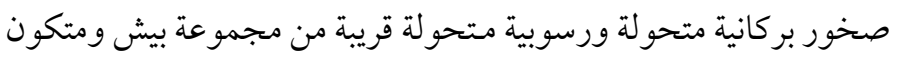

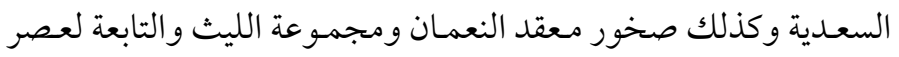

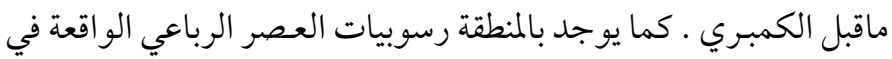

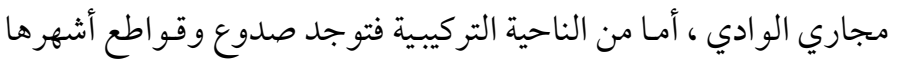

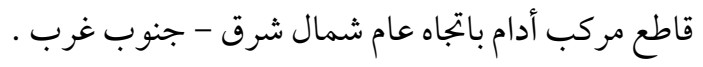

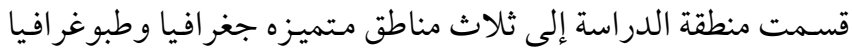

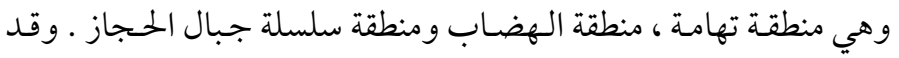

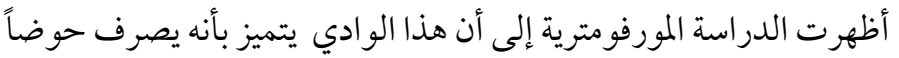

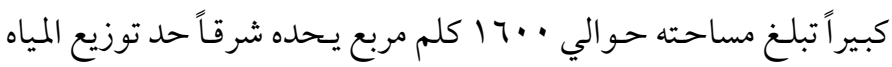

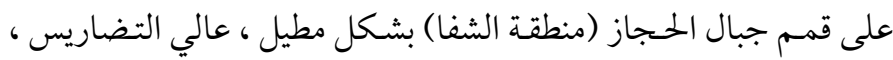
متوسط كثافة التصريف ورتبتة الرابعة .

يو جد في الوادي مياه جارية محلية في أعلى الوادي طوال أيام السنة .

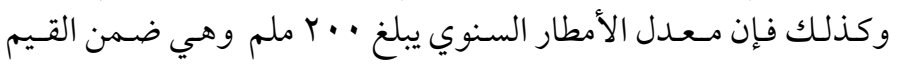

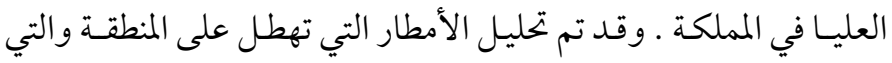

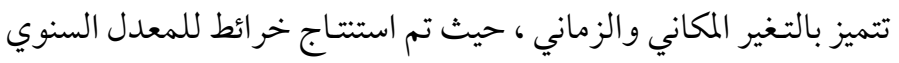

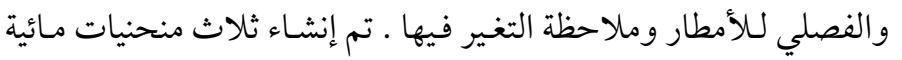




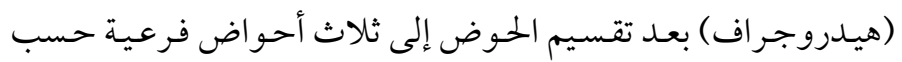

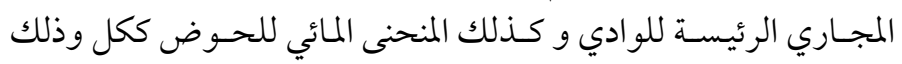

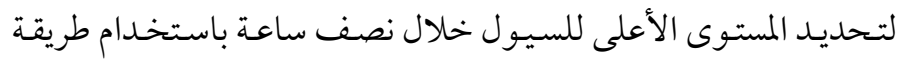
الافتراضية لعدم وجود معلومـات كافية داخل الحوض للأمطار

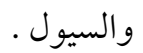

